\title{
STRATEGI MANAJEMEN MENINGKATKAN KINERJA DAN PELAYANAN ANGGOTA KOPERASI PRODUKSI PEDAGANG KOTA DEPOK
}

\author{
Oleh: \\ Dhona Shahreza ${ }^{1}$ \\ Lindiawatie $^{2}$ \\ ${ }^{1 \& 2)}$ Fakultas Ilmu Pendidikan dan Pengetahuan Sosial \\ Universitas Indraprasta PGRI Jakarta \\ Email: \\ dhona.shahreza@unindra.ac.id
}

\begin{abstract}
ABSTRAK
Koperasi Produksi Pedagang Kota Depok (KPPD) berdiri sejak 2016 namun kehadirannya tidak mampu menarik pedagang mikro dan kecil di pasar untuk aktif menjadi anggota. Bahkan, kini hanya 50 orang anggota yang aktif dari 300 orang yang terdaftar. Penelitian ini bertujuan untuk merumuskan strategi manajemen KPPD dalam meningkatkan kinerja dan pelayanan kepada anggotanya. Metode kualitatif deskriptif diterapkan dengan pengumpulan data melalui wawancara terstruktur dan semi terstruktur terhadap pengurus dan pengelola koperasi, dokumentasi dan observasi langsung ke koperasi. Teknik analisis data menggunakan analisis SWOT dengan mengidentifikasi faktor eksternal dan internal untuk mendapatkan matriks SWOT. Hasil penelitian merumuskan strategi manajemen yang fokus pada peningkatan aset dan profit dengan cara membuat dan meningkatkan kualitas produk/jasa dan memperluas saluran pemasaran. Adapun strategispesifik yang dirumuskan berupa: 1) Strategi SO dengan cara meningkatkan kualitas SDM, Perluasan usaha tidak saja berupa simpan pinjam, meningkatkan komitmen pengurus, Memperkuat pangsa pasar; 2) Strategi STdengancara membangun fasilitas yang memadai, meningkatkan kepercayaan anggota dan calon anggota, menetapkan strategi pemasaran; 3) Strategi WOdengancara menambah modal baru, memperketat syarat pinjaman, meningkatkan komitmen anggota,meningkatkan promosi, meningkatkan kualtitas pelayanan dan 4) Strategi WT dengan cara meningkatkan strategi manajemen yang efektif dan efisien, menampilkan keunggulan produk yang berdaya saing, bekerja sama dengan pemerintah untuk memperkuat koperasi.
\end{abstract}

Kata kunci: Kinerja, Koperasi; Pelayanan; Strategi manajemen 


\begin{abstract}
Koperasi Produksi Pedagang Kota Depok (KPPD) was established in 2016 but it could not make market's micro and small traders become active members. In fact, there are only 50 of 300 members registered as an active member.This study aims to formulate the management strategies of KPPD to improve performance and services to its members. Descriptive qualitative method is conducted which data collected using structured interviews, library research and observation. SWOT analysisis carried out by identifying internal and external factors to create SWOT matrix. The results of the study formulate management strategy that focuses on diversification of business, product and distribution which specifically formulate: 1) The SO strategy: to improve human resource quality, diversifivication product not only saving and loan, to improve cooperative management and to strengthen market share; 2) The ST strategy: to build adequate facilities, to improve the trust of members as well as the candidates and to determine management strategy; 3) The WO strategy: to increase new capital, to tighten loan terms, to improve members commitment, to increase promotion and to improve service quality; 4) The WT strategy: to improve effective and efficient management strategy, to perform product comparative advantages, and to work together with government.
\end{abstract}

Keywords: Cooperative, Management Strategy, Performance, Services,.

\title{
A. PENDAHULUAN
}

Koperasi di Indonesia sesuai Pasal 33 ayat 1 UUD tahun 1945 menyatakan bahwa perekonomian disusun sebagai usaha bersama berdasarkan asas kekeluargaan. Koperasi harus tampil sebagai organisasi yang dapat mengumpulkan dan membentuk kekuatan ekonomi bersama-sama untuk mencapai tingkat kesejahteraan yang lebih baik bagi anggotanya (Mawikere, 2014). Keberadaan koperasi dipandang penting jika pengembangan aktivitas ekonomi berwawasan ke arah untuk meningkatkan martabat dan harkat anggotanya dan masyarakat secara luas baik secara langsung maupun tidak langsung (Suhartono, 2011). Secara lebih mendalam, selain mengutamakan prinsip tolong menolong, kerjasama dan saling memenuhi kebutuhan, koperasi juga merupakan salah satu organisasi yang ikut serta bersaing memperebutkan pelanggan baik internal (anggota) maupun eksternal (non anggota). Keberlangsungan koperasi hanya akan terus dirasakan jika koperasi memiliki keunggulan bersaing dari pesaing dalam industri yang sama (Sari, 2016)

Koperasi produksi adalah koperasi yang didirikan untuk menyediakan produk yang dihasilkan oleh para anggotanya. Disini, koperasi bisa saja beranggotakan individu yang berperan sebagai karyawan produksi sekaligus pemiliknya atau bisa saja beranggotakan para pengusaha yang berkumpul untuk menyatukan produk usahanya (Sudarsono \& Edilius, 2005).

Kinerja adalah gambaran mengenai tingkat pencapaian pelaksanaan suatu program kegiatan atau kebijakan dalam mewujudkan sasaran, tujuan, visi, dan misi organisasi yang dituangkan melalui perencanaan strategis suatu organisasi 
(Moeheriono, 2012). Perencanaan ini kemudian dikelola dalam suatu rangkaian yang disebut manajemen strategis.

Manajemen strategis adalah satu set keputusan dan tindakan yang menghasilkan formulasi dan implementasi rencana yang dirancang untuk meraih tujuan suatu perusahaan (Pearce II \& Robinson, Jr, 2008).

Pelayanan adalah suatu aktivitas atau serangkaian aktivitas yang bersifat tidak kasat mata (tidak dapat diraba) yang terjadi sebagai akibat adanya interaksi antara konsumen dengan karyawan atau hal lain yang disediakan oleh perusahaan pemberian pelayanan yang dimaksud untuk memecahkan permasalahan atau pelanggan (Daryanto \& Setiabudi, 2014).

Analisis SWOT adalah identifikasi berbagai faktor secara sistematis yang merumuskan strategi perusahaan yang didasarkan logika yang dapat memaksimalkan kekuatan (strength) dan peluang (opportunities), dan secara bersamaan dapat meminimalkan kelemahan (weakness) dan ancaman (threats) (Rangkuti F. , 2006)

Beberapa penelitian sudah dilakukan untuk merumuskan strategi manajemen, seperti penelitian (Sari, 2016) yang menggunakan faktor bauran pemasaran dimana strategi yang digunakan adalah personal selling, memberikan fasilitas yang memuaskan bagi nasabah dan jemput bola dengan posisi koperasi berada pada kuadran satu, yaitu kuat dan berpeluang. Penelitian ini berbeda dengan penelitian sebelumnya karena Koperasi Produksi Pedagang Kota Depok adalah koperasi yang baru berjalan kurang dari dua tahun sehingga penelitian berfokus pada strategi manajemen secara umum untuk membantu persoalan koperasi yang baru berdiri agar jelas strateginya.

Permasalahan yang dihadapi sebagian besar koperasi saat ini seperti yang tercantum dalam Rencana Pembangunan Jangka Menengah Daerah (RPJMD) Propinsi Jawa Barat tahun 2013-2018 (Hanny, Kurniawati, Waruwu, \& Pribadi, 2017) adalah: 1) Tingkat partisipasi anggota dalam proses pengembangan kegiatan organisasinya yang masih rendah; 2) kualitas dan kuantitas SDM, akses pasar, akses kelembagaan, akses pembiayaan dan informasi serta penggunaan teknologi tepat guna yang masih minim; 3) Tingkat Inovasi dan pengembangan produknya masih minim; dan 4) Produk koperasi memiliki daya saing yang lebih rendah jika dibandingkan dengan produk impor. Oleh sebab itu, strategi manajemen yang tepat perlu dirancang dalam pengelolaan koperasi terutama dalam hal pelayanan dan kinerja agar tujuan menjadi koperasi yang berdaya saing dapat terwujud.

Bagi kota Depok, Dinas Koperasi, UKM, dan Pasar Kota Depok mencatat sedikitnya terdapat 657 koperasi yang tersebar di 11 kecamatan. Namun, hanya 345 koperasi yang masih aktif $(52,5 \%)$, sementara sisanya kurang bergeliat atau kurang aktif. Koperasi yang kurang aktif rata-rata tidak rutin menggelar RAT atau kurang menggelar program kegiatan. Anggaran dana bergulir yang diberikan oleh Lembaga Pengelola Dana Bergulir KUKM (LPDB KUKM) kepada koperasi pun bukannya sedikit, yakni sebesar 8,5 triliun rupiah yang digulirkan sejak 2008. Ada anggaran setiap tahun yang cukup besar namun penyaluran kepada koperasi masih sangat kecil (www.ekbis.sindonews.com, 21 Agustus 2018). Ini disebabkan pola dan sistem yang tak berjalan dengan lancar. Selain itu banyak dana bergulir 
yang tidak kembali disebabkan persepsi masyarakat bahwa dana pembiayaan koperasi tersebut adalah hibah. Padahal dana tersebut bukan dana hibah melainkan dana bantuan yang tetap harus dikembalikan kepada LPDB KUKM.

Koperasi Produksi Pedagang Kota Depok didirikan pada tanggal 26 Februari 2016 dengan berlokasi di Pasar Agung Depok. Koperasi ini berdiri dengan didasari kurangnya wadah atau lembaga yang dapat mendukung dan memfasilitasi pedagang dalam usahanya. Koperasi yang baru berdiri kurang dari dua tahun ini memerlukan strategi manajemen agar dapat berkembang dalam hal pengelolaan koperasi terutama faktor kinerja dan pelayanan yang masih sangat minim. Kinerja yang masih minim dibuktikan dari data wawancara terhadap pengelola yang menyatakan penurunan jumlah anggota yang mendaftar di awal koperasi berdiri pada awal 2016, dari 300 orang yang mendaftar hanya 50 anggota yang aktif setelah dua tahun berjalan. Koperasi dimanfaatkan oleh anggota yang baru mendaftar hanya untuk memperoleh pinjaman kemudian banyak anggota yang mengabaikan pengembalian pinjaman sehingga keberlangsungan koperasi terhambat. Para pedagang pasar hanya sekedar mendaftar jadi anggota namun tidak mau membayar simpanan wajib dan simpanan pokok. Pedagang pasar hanya berniat meminjam namun tidak mau menabung.

Tujuan penelitian ini adalah untuk merumuskan strategi manajemen dalam meningkatkan kinerja dan pelayanan untuk anggota di Koperasi Produksi Pedagang Kota Depok. Manfaat penelitian ini diharapkan dapat menjadi referensi serta menjadi bahan pertimbangan bagi Koperasi Produksi Pedagang Kota Depok dalam membuat keputusan strategi manajemen sebagai upaya meningkatkan pelayanan bagi anggota. berikut:

Sedangkan kerangka berpikir penelitian ini dipelihatkan pada Gambar 1

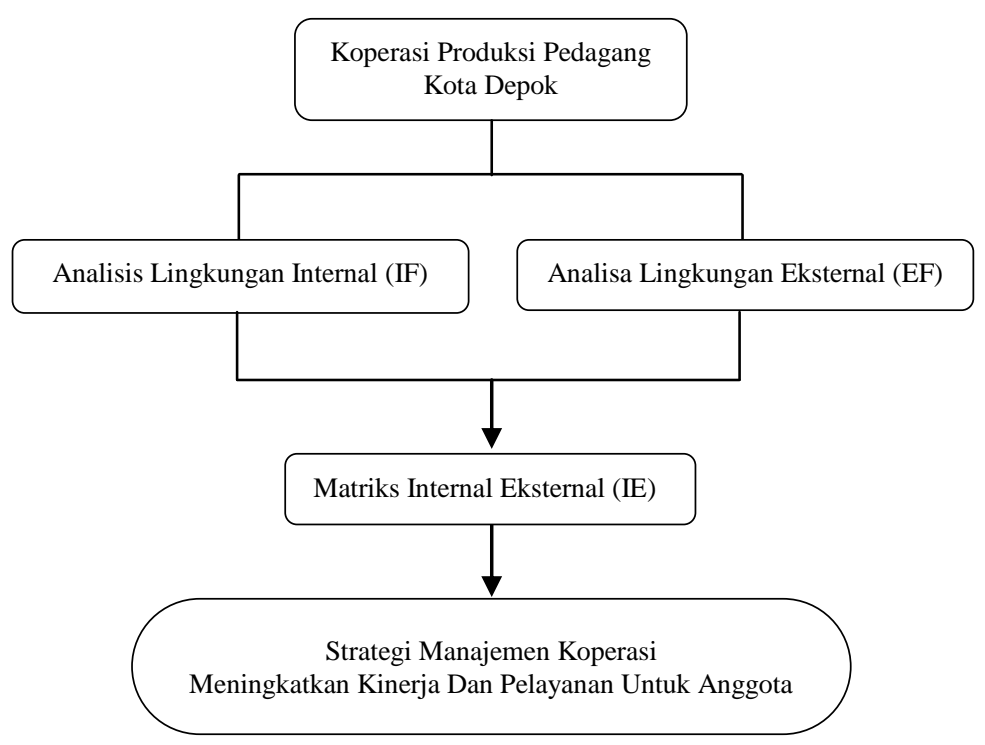

Gambar 1. Kerangka Berpikir Penelitian 


\section{B. METODE PENELITIAN}

\section{Jenis Penelitian}

Penelitian ini merupakan penelitian kualitatif deskriptif. Menurut (Nassaji, 2015) istilah kualitatif dan deskriptif digunakan secara bertukaran. Pada jenis penelitian kualitatif deskriptif atau deskriptif kualitatif. Pengumpulan data yang dilakukan secara kualitatif diperoleh dari berbagai sumber untuk menggali lebih dalam pemahaman partisipan yang meliputi persepsi, pendapat dan perilaku. Pengolahan data dapat dilakukan secara kualitatif ataupun kuantitatif.

Metode penelitian kualitatif adalah penelitian yang berlandaskan pada filsafat postpositivisme, digunakan untuk meneliti kondisi obyek yang alamiah dimana peneliti adalah sebagai instrumen kunci (Sugiyono, 2007). Sementara itu, (Arikunto, 2006) menjelaskan bahwa penelitian deskriptif adalah suatu penelitian yang bertujuan untuk menggambarkan atau memaparkan sesuatu hal. Misalnya keadaan, kondisi, situasi, peristiwa, kegiatan dan lain-lain. Peneliti mendatangi tempat koperasi berada dan mengobservasi keadaan di lapangan yang meliputi kondisi fisik kantor koperasi dan situasi lingkungan internal dan eksternal pasar seperti kebersihan, fasilitas pendukung seperti lapangan parkir, toilet, ATM dan lain-lain serta gambaran umum para pedagang yang berjualan di pasar tersebut.

Penelitian dilakukan di Koperasi Produksi Pedagang Kota Depok selama bulan September sampai Desember 2018. Obyek penelitian adalah pimpinan Koperasi Pedagang Kota Depok yang terdiri dari pengurus dan pengelola yang memahami proses berdiri dan jalannya koperasi selama ini. Sedangkan anggota Koperasi adalah para pedagang pasar yang kebanyakan merupakan pedagang mikro dan kecil di bidang penjualan pakaian dan makanan.

\section{Metode Pengumpulan Data}

Penelitian ini menggunakan beberapa teknik pengumpulan data, yaitu: 1) Observasi. Metode observasi digunakan untuk memperoleh data yang akurat tentang keadaan di lapangan dengan melakukan pengamatan langsung (Sugiyono, 2007). Observasi dilakukan secara tidak berstruktur, yaitu observasi yang tidak dipersiapkan secara sistematis tentang apa yang akan diobservasi Hal ini dilakukan karena peneliti tidak tahu secara pasti tentang apa yang akan diamati. Dalam melakukan pengamatan peneliti tidak menggunakan instrumen yang telah baku, tetapi hanya berupa rambu-rambu pengamatan. Observasi dilakukan pada KPPD dengan tujuan mendapatkan data primer dan untuk membuktikan kebenaran data yang diperoleh dari wawancara yang dilakukan; 2) Wawancara.Menurut (Sukandarmidi, 2012) wawancara merupakan proses informasi tanya jawab lisan, dimana dua orang atau lebih berhadapan secara fisik, yang satu dapat melihat muka yang lain dan mendengar dengan telinga sendiri dengan suaranya.Teknik wawancara dalam penelitian ini dilakukan dengan mewawancarai secara terstruktur yang sudah dipersiapkan daftar pertanyaan oleh peneliti dan semi terstruktur yang akan menyesuaikan saat wawancara berlangsung di lapangan terhadap pengurus dan pengelola Koperasi Produksi Pedagang Kota Depok untuk mendapatkan informasi sebagai bahan acuan bagi strategi pemasaran dan faktor-faktor lingkungan internal maupun eksternal untuk 
keperluan analisis SWOT; dan 3) Dokumentasi, dilakukan dengan dengan cara mengumpulkan dokumen dan berbagai literatur yang berkaitan dengan penelitian. Dokumen-dokumen yang dibutuhkan adalah dokumen akta pendirian koperasi, profil koperasi yang meliputi sejarah, AD/ART, keanggotaan, UU koperasi dan hasil Rapat Anggota Tahunan 2017 yang pertama diselenggarakan, profil pasar Agung Depok dari Dinas Koperasi Depok.

\section{Teknik Analisis Data}

Tahapan analisis data yang dikembangkan dalam penelitian ini adalah: 1) Reduksi data (identifikasi) faktor eksternal dan internal. Tahapan ini mengidentifikasi faktor eksternal berupa faktor peluang dan ancaman dan internal berupa faktor kekuatan dan kelemahan dari Koperasi Produksi Pedagang Kota Depok; 2) Display data. Pada tahapan ini peneliti menggunakan diagram MatriksInternal Eksternal (IE) dan SWOT; dan 3) Interpretasi hasil analisis Matriks IE dan SWOT.Matrik Internal dan Eksternal (IE) dikembangkan dari model General Electric (GE Model). Elemen yang digunakan meliputi parameter kekuatan internal perusahaan dan pengaruh eksternal yang dihadapi. Tujuan penggunaan model ini adalah untuk memperoleh strategi bisnis di tingkat korporat yang lebih detil (Rangkuti F. , 2006) melalui Matriks Internal-Ekstenal (IE) yang ditunjukkan pada Gambar 2 berikut:

\begin{tabular}{|c|c|c|c|}
\hline 4.00 & Kuat & Rata-rata & Lemah \\
\hline TINGGI & $\begin{array}{l}\text { 1. Growth konsentrasi } \\
\text { melalui integrasi } \\
\text { vertikal }\end{array}$ & $\begin{array}{l}\text { 2. Growth konsentrasi melalui } \\
\text { integrasi Horizontal }\end{array}$ & $\begin{array}{l}\text { 3. Retrenchment strategi turn } \\
\text { around }\end{array}$ \\
\hline $\begin{array}{c}\text { SEDANG } \\
2.00\end{array}$ & 4. Stability & $\begin{array}{l}\text { 5. Growth konsentrasi melalui } \\
\text { strategi integrasi horizontal }\end{array}$ & $\begin{array}{l}\text { 6. Retrenchment strategi } \\
\text { divestasi }\end{array}$ \\
\hline RENDAH & $\begin{array}{l}\text { 7. Growth } \\
\text { diversifikasi } \\
\text { konsentrrik }\end{array}$ & $\begin{array}{l}\text { 8. Growth diversifikasi } \\
\text { diversifikasi konglomerat }\end{array}$ & $\begin{array}{l}\text { 9. Retrenchment } \\
\text { Likuiditas atau bangkrut }\end{array}$ \\
\hline
\end{tabular}

Sumber: (Rangkuti F. , 2006)

\section{Gambar 2. Matriks Internal dan Eksternal}

Keterangan:

1) Growth strategy merupakan pertumbuhan perusahaan itu sendiri.

2) Stability strategy adalah strategi yang diterapkan tanpa mengubah arah strategi yang telah ditetapkan

3) Rentrechment strategy adalah usaha memperkecil ataua mengurangi usaha yang dilakukan

Untuk memperoleh penjelasan secara detil mengenai strategi pada matrik IE, maka akan dijelaskan tindakan dari masing-masing strategi tersebut: 
1) Konsentrasi melalui integrasi vertikal dapat dicapai dengan cara mengambil alih fungsi supplier atau dengan cara mengambil alih fungsi distributor. Hal ini merupakan startegi utama perusahaan yang memiliki posisi kompetitif pasar yang kuat dalam industri yang berdaya saing tinggi.

2) Strategi pertumbuhan melalui integrasi horisontal ialah dengan cara memperluas lini produk dan saluran distribusinya ke wilayah-wilayah potensial lainnya secara intensif.

3) Strategi turn around ialah strategi yangdigunakan untuk menyehatkan kembali perusahaan.

4) Strategi divestasi ialah strategi yang digunakan untuk menggali modal dengan menjual aset non produktif dan aset produktif untuk selanjutnya digunakan untuk mendanai akuisisi atau investasi.

5) Diversifikasi konsentrik ialah strategi pertumbuhan yang dilakukan dengan cara membuat produk baru secaara efisien karena perusahaan sudah memiliki kemampuan manufaktur dan pemasaran yang baik.

6) Diversifikasi konglomerat ialah strategi pertumbuhan melalui kegiatan bisnis yang tidak saling berhubungan dan dapat dilakukan jika perusahaan menghadapi competitive position yang tidak begitu kuat dan nilai daya tarik industrinya sangat rendah. Kedua faktor tersebut memaksa perusahaan untuk melakukan usahanya ke dalam perusahaan lain.

7) Strategi likuidasi ialah strategi yang menjual aset perusahaan yang bernilai nyata.

Matriks SWOT adalah alat yang dapat menunjukkan keadaan suatu perusahaan dan kedudukannya dalam persaingan. Matriks ini digunakan sebagai alat bantu dalam merumuskan siasat-siasat berdasarkan peluang-peluang, ancaman-ancaman, kekuatan-kekuatan, dan kelemahan-kelemahan yang sudah ditetapkan melalui kajian SWOT(Pardede, 2011). Matriks ini dapat menghasilkan empat set kemungkinan alternatif strategi yang ditunjukkan dengan Tabel 1 di bawah ini.

\section{Tabel 1. Matriks SWOT}

\begin{tabular}{|c|c|c|}
\hline $\begin{array}{l}\text { Faktor-Faktor } \\
\text { (IFAS) }\end{array}$ & $\begin{array}{l}\text { Kekuatan (S) } \\
\text { Daftarkan } \quad 5-10\end{array}$ & $\begin{array}{l}\text { Kelemahan }(W) \\
\text { Daftarkan } \quad 5-10\end{array}$ \\
\hline $\begin{array}{l}\text { Faktor-Faktor } \\
\text { (EFAS) }\end{array}$ & Faktor Internal & Fak \\
\hline $\begin{array}{l}\text { Peluang }(\mathrm{O}) \\
\text { Daftarkan 5-10 faktor-faktor } \\
\text { peluang eksternal }\end{array}$ & $\begin{array}{l}\text { Straategi (SO) } \\
\text { Buat strategi di sini yang } \\
\text { menggunakan kekuatan untuk } \\
\text { memanfaatkan peluang }\end{array}$ & $\begin{array}{l}\text { Strategi (WO) } \\
\text { Buat strategi di sini yang } \\
\begin{array}{l}\text { memanfaatkan } \\
\text { mengatasi ancaman }\end{array}\end{array}$ \\
\hline $\begin{array}{l}\text { Ancaman }(\mathrm{T}) \\
\text { Daftarkan 5-10 faktor-faktor } \\
\text { ancaman eksternal }\end{array}$ & $\begin{array}{l}\text { Strategi (ST) } \\
\text { Buat strategi di sini yang } \\
\text { menggunakan kekuatan untuk } \\
\text { mengatasi ancaman }\end{array}$ & $\begin{array}{l}\text { Strategi (WT) } \\
\text { Buat strategi di sini yang } \\
\text { meminimalkan kelemahan dan } \\
\text { menghindari ancaman }\end{array}$ \\
\hline
\end{tabular}

Tahap selanjutnya adalah melakukan identifikasi cara atau alternatif yang dapat menggunakan kesempatan dan peluang atau menghindari ancaman dan mengatasi kelemahan. Berikut ini ditunjukkan Diagram SWOT. 


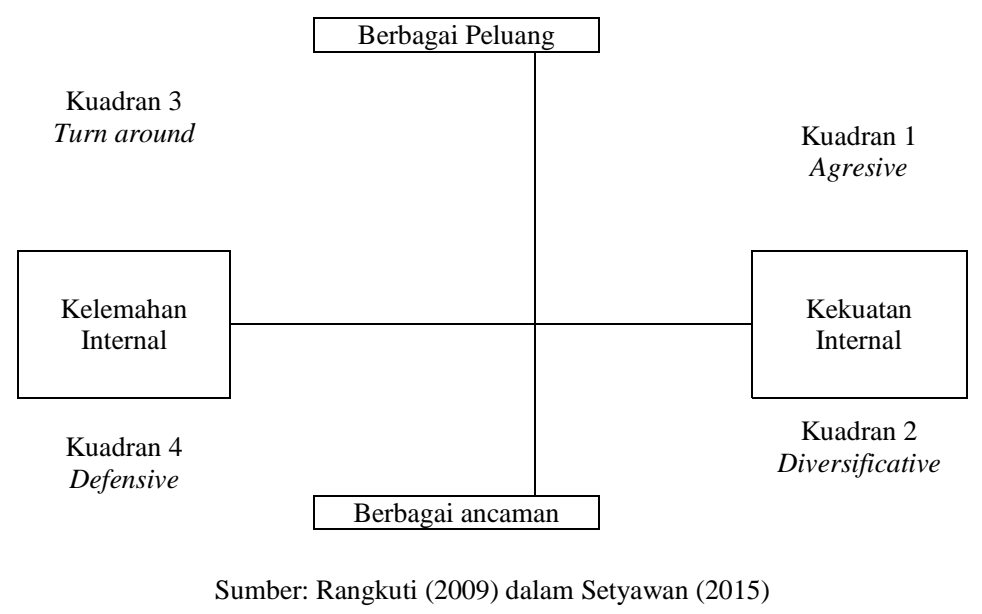

Gambar 3 Diagram SWOT

Keterangan:

1) Kuadran 1. Merupakan situasi yang sangat menguntungkan. Perusahaan tersebut memiliki peluang dan keuatan sehingga dapat memanfaatkan peluang yang ada. Strategi yang harus diterapkan dalam kondisi ini adalah mendukung kebijakan pertumbuhan yang agresif (Growth Oriented Strategy)

2) Kuadran 2. Meskipun menghadapi berbagai ancaman, perusahaan ini masih memiliki kekuatan dari segi internal. Strategi yang harus diterapkan adalah menggunakan kekuatan untuk memanfaatkan peluang jangka panjang dengan cara strategi diversifikasi (produk/jasa).

3) Kuadran 3. Perusahaan menghadapi peluang pasar yang sangat besar, tetapi dilain pihak, ia menghadapi beberapa kendala/kelemahan internal. Fokus perusahaan ini adalah meminimalkan masalah-masalah internal perusahaan sehingga dapat merebut peluang pasar yang lebih baik.

4) Kuadran 4. Ini merupakan situasi yang sangat tidak menguntungkan. Perusahaan tersebut menghadapi berbagai ancaman dan kelemahan internal.

\section{HASIL DAN PEMBAHASAN}

\section{Gambaran Umum Koperasi Pedagang Kota Depok}

Modal awal berdirinya koperasi berasal dari dana pribadi Bapak Haji Kirno seorang pengusaha kecil yang berdagang ayam di pasar Agung, Depok. Modal awal sebesar Rp 30 juta. Pemrakarsa koperasi berjumlah 5 orang. Simpanan pokok Rp 350.000,00 dan simpanan wajib Rp 50.000 per bulan. Anggota koperasi tersebar tidak hanya di Pasar Agung tetapi juga di Pasar Pal Tugu dan pasar Cisalak. Profesi anggota sebagai pedagang pakaian dan makanan. Bidang usaha distributor/produksi dan simpan-pinjam. Besar pinjaman mulai dari 1-25 juta. Semboyan dari Koperasi Produksi Pedagang Kota Depok adalah bekerja dengan jujur, ramah, senyum dan bersahabat. Koperasi Produksi Pedagang Kota Depok bertujuan untuk memajukan kesejahteraan anggota pada khususnya dan masyarakat pada umumnya serta ikut membangun tatanan perekonomian nasional dalam rangka mewujudkan masyarakaat yang adil dan makmur. Anggota 
Koperasi Produksi Pedagang Kota Depok seluruhnya berjumlah 250 orang. Visi koperasi adalah menjadi koperasi terbaik di kota Depok. Sedangkan misi Koperasi Produksi Pedagang Kota Depok antara lain: 1) Menciptakan kesejahteraan bagi para anggota yang berkesinambungan; 2) Berdaya guna sebagai mitra strategi dan terpercaya bagi anggota; 3) Berkontribusi dalam perkembangan perkoperasian Indonesia; dan 4) Mengelola koperasi dan unit usaha secara profesional dengan menerapkan "Good Corporate Governance".

\section{Hasil Penelitian}

\section{Matriks Internal-Eksternal (IE) Koperasi}

Untuk mendapatkan matriks IE dilakukan analisis terhadap lingkungan internal dan eksternal pada Koperasi Produksi Pedagang Kota Depok (KPPD) yang meliputi pemasaran, keuangan, produksi/operasional, dan sumber daya manusia. Hasil analisis faktor-faktor internal disajikan disajikan pada Tabel 2 berikut.

\section{Faktor-Faktor Internal KPPD}

Tabel 2. Daftar Faktor-Faktor Internal Koperasi

\begin{tabular}{|c|c|c|c|c|}
\hline \multirow{2}{*}{ No } & Faktor-Faktor Internal & \multirow{2}{*}{ Bobot } & \multirow{2}{*}{ Rating } & \multirow{2}{*}{$\begin{array}{c}\text { Bobot X } \\
\text { Rating }\end{array}$} \\
\hline & Kekuatan & & & \\
\hline 1. & 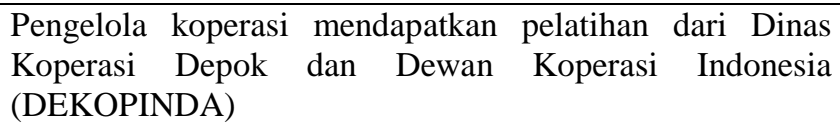 & 0.025 & 3 & 0.075 \\
\hline 2. & Pemasaran dilakukan secara mulut ke mulut & 0.10 & 4 & 0.40 \\
\hline 3. & Memiliki visi dan misi sebagai organisasi koperasi & 0.05 & 3 & 0.15 \\
\hline 4. & Perngurusan pinjaman mudah dan tidak berbelit-belit & 0.05 & 3 & 0.15 \\
\hline 5. & Bekerja sama dengan Tunas Mandiri Finance & 0.025 & 3 & 0.075 \\
\hline 6. & Pengurus berkomitmen memajukan koperasi dan anggota & 0.05 & 4 & 0.2 \\
\hline 7. & $\begin{array}{l}\text { Pengambilan keputusan secara cepat dan singkat karena } \\
\text { pemrakarsa } 5 \text { orang selalu berada di pasar }\end{array}$ & 0.025 & 3 & 0.075 \\
\hline 8 & $\begin{array}{l}\text { Penagihan pinjaman dilakukan setiap hari kurang dari } 1 \\
\text { jam karena anggota koperasi berada di pasar setiap hari }\end{array}$ & 0.025 & 3 & 0.075 \\
\hline No & Kelemahan & & & \\
\hline 1. & $\begin{array}{l}\text { Modal awal berasal dari } 1 \text { orang yang mensubsidi biaya } \\
\text { operasi bulanan seperti gaji pegawai, sewa dan listrik }\end{array}$ & 0.1 & 2 & 0.20 \\
\hline 2. & Syarat keanggotan tidak jelas/tidak tegas & 0.025 & 1 & 0.025 \\
\hline 3. & Pinjaman juga diberikan kepada non anggota & 0.05 & 1 & 0.05 \\
\hline 4. & Kesulitan menagih pinjaman kepada anggota & 0.10 & 1 & 0.10 \\
\hline 5. & Pengurus merangkap pengelola & 0.05 & 2 & 0.10 \\
\hline 6. & Sistem pembukuan manual & 0.05 & 1 & 0.05 \\
\hline 7. & Anggota kurang tertarik menabung & 0.10 & 1 & 0.10 \\
\hline 8. & $\begin{array}{l}\text { Anggota banyak mengabaikan kewajiban untuk } \\
\text { mengembalikan pinjaman. }\end{array}$ & 0.10 & 1 & 0.10 \\
\hline 9. & Citra koperasi buruk dimata pedagang & 0.05 & 1 & 0.05 \\
\hline 10. & Jam operasional singkat. & 0.05 & 1 & 0.05 \\
\hline & Total & 1.00 & & 2.025 \\
\hline
\end{tabular}


Pada Tabel 2 di atas diperlihatkan faktor-faktor internal koperasi yang meliputi faktor kelemahan koperasi yang terdapat 8 data yang dikategorikan datadata kekuatan koperasi dan 10 data dikategorikan data-data kelemahan koperasi. Setelah masing-masing data dinilai bobot dan ratingnya akhirnya diperoleh hasil perkalian bobot dan rating masing-masing data. Skor total yang diperoleh sebesar 2.025 .

Faktor-Faktor Eksternal KPPD

Tabel 3. Daftar Faktor-Faktor Eksternal Koperasi

\begin{tabular}{|c|c|c|c|c|}
\hline \multirow{2}{*}{ No } & Faktor-Faktor Eksternal & \multirow{2}{*}{ Bobot } & \multirow{2}{*}{ Rating } & \multirow{2}{*}{ Bobot $x$ Rating } \\
\hline & Peluang & & & \\
\hline 1. & $\begin{array}{lll}\text { Koperasi melakukan kegiatan } & \text { produksi } \\
\text { bermitra dengan perusahaan } & \text { konveksi } \\
\text { memperoduksi pakaian anak } & \end{array}$ & 0.15 & 3 & 0.45 \\
\hline 2. & $\begin{array}{l}\text { Menarik anggota baru karena jumlah } \\
\text { pedagang yang banyak }\end{array}$ & 0.20 & 4 & 0.80 \\
\hline 3. & $\begin{array}{l}\text { Bekerjasama dengan pihak UPTD Pemda } \\
\text { Depok yang bertanggungjawab mengelola } \\
\text { pasar }\end{array}$ & 0.10 & 2 & 0.20 \\
\hline 4. & $\begin{array}{l}\text { Wacana bantuan dana dari Kementrian } \\
\text { Koperasi }\end{array}$ & 0.10 & 3 & 0.30 \\
\hline No & Ancaman & & & \\
\hline 1 & $\begin{array}{l}\text { Adanya pasar kaget yang berunculan di akhir } \\
\text { pekan }\end{array}$ & 0.10 & 2 & 0.20 \\
\hline 2. & $\begin{array}{l}\text { Munculnya supermarket besar yang } \\
\text { mengalihkan minat konsumen berbelanja }\end{array}$ & 0.05 & 2 & 0.10 \\
\hline 3. & Fasilitas pasar yang tidak memadai & 0.20 & 3 & 0.60 \\
\hline 4. & $\begin{array}{l}\text { Banyaknya kios yang sepi penjual dan } \\
\text { pembeli terutama di lantai atas tempat } \\
\text { koperasi berada }\end{array}$ & 0.10 & 3 & 0.30 \\
\hline & Total & 1 & & 2.95 \\
\hline
\end{tabular}

Berdasarkan skor analisis lingkungan eksternal (EF) yang meliputi 4 data dikategorikan data peluang dan 4 data dikategorikan data-data ancaman pada Tabel 3 di atas, diperoleh total skor akhir sebesar 2,95.

Dengan demikian skor akhir masing-masing data-data faktor internal dan eksternal telah diperoleh yaitu skor 2,025 untuk skor kekuatan dan kelemahan (internal) dan skor 2,95 untuk peluang ancaman (eksternal). Selanjutnya untuk melihat strategi yang tepat guna diterapkan dianalisa dengan Matriks InternalEkstenal (IE) berikut: 


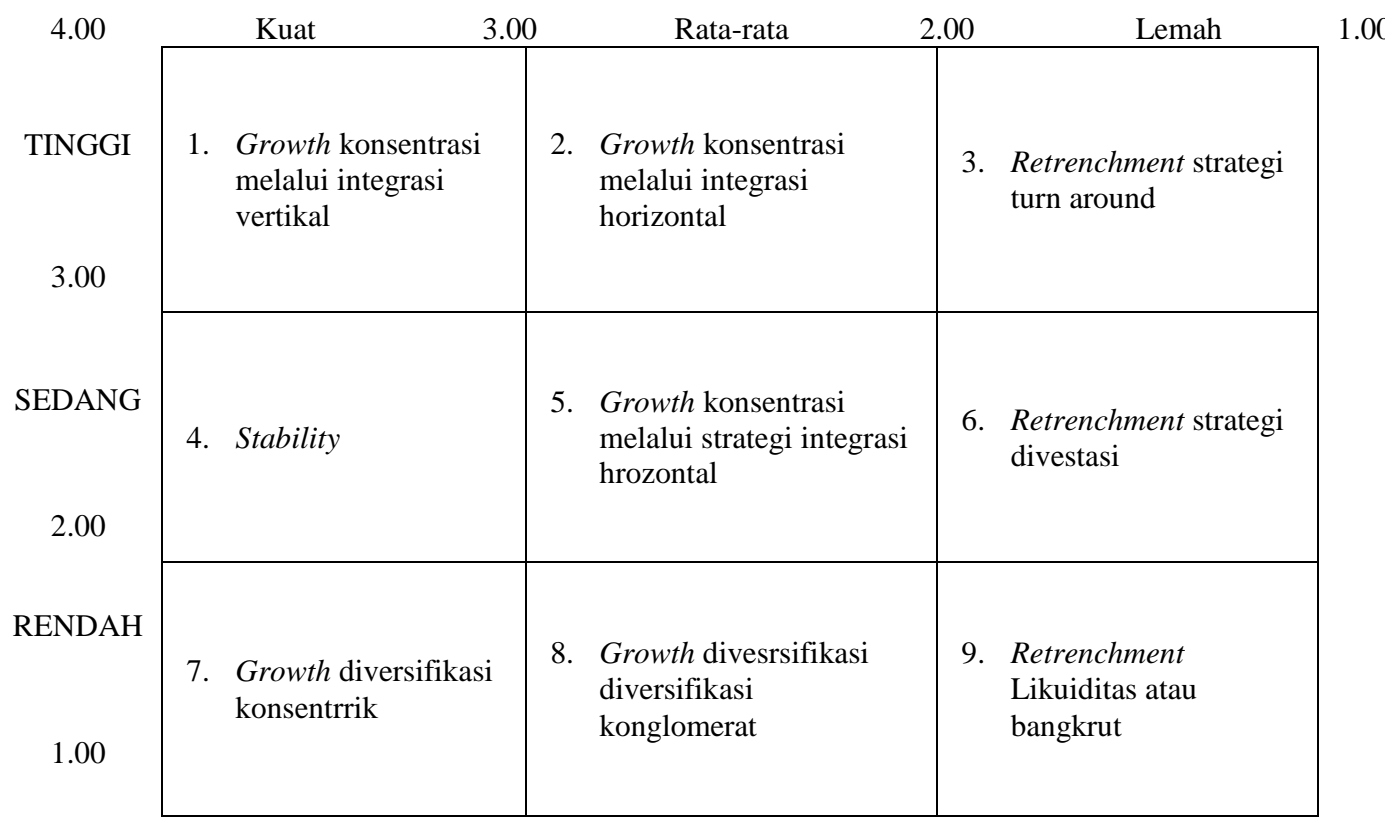

\section{Gambar 3. Matriks Internal Eksternal (IE) KPPD}

Berdasarkan matriks IE pada Gambar 3 di atas diperlihatkan bahwa irisan skor faktor internal dan eksternal KPPD diperlihatkan pada kolom 5 dengan skor yang dikategorikan rata-rata sedang yang berada di kisaran interval skor 2,00 3,00.yang bermakna KPPD hendaknya fokus pada growth konsentrasi melalui strategi integrasi horizontal.

\section{Matrik SWOT}

Menurut (Rangkuti F. , 2010) beberapa model atau teknik analisa dapat digunakan sekaligus unuk memperoleh hasil analisis yang lebih lengkap dan akurat. Untuk memahami lebih dalam maka analisis dalam penelitian ini menggunakan pula matriks SWOT yang bertujuan untuk menguatkan hasil dari analisis Matriks Internal Eksternal (IE) KPPD yang diperlihatkan pada Tabel 4 berikut ini:

Tabel 4. Matrik SWOT

\begin{tabular}{|c|c|c|}
\hline \multirow[t]{11}{*}{ Faktor Internal } & Kekuatan & Kelemahan \\
\hline & Pengelola & Modal awal berasal dari 1 \\
\hline & mendapatkan pelatihan dari & orang yang mensubsidi biaya \\
\hline & Dinas Koperasi Depok dan & operasi bulanan seperti gaji \\
\hline & Dewan Koperasi Indonesia & pegawai, sewa dan listrik \\
\hline & $\begin{array}{l}\text { (DEKOPINDA) } \\
\text { Pemasaran dilakukan }\end{array}$ & $\begin{array}{l}\text { 2. Syarat keanggotan tidak } \\
\text { jelas/tidak tegas }\end{array}$ \\
\hline & mulut ke mulut & 3. Pinjaman juga diberikan \\
\hline & 3. Memiliki visi dan misi sebagai & kepada non anggota \\
\hline & organisasi koperasi & 4. Kesulitan menagih pinjaman \\
\hline & 4. Perngurusan pinjaman mudah & $\begin{array}{ll} & \text { kepada anggota } \\
5 & \text { Pengurus merangkan }\end{array}$ \\
\hline & 5. Bekerja sama dengan Tunas & pengelola \\
\hline
\end{tabular}




\begin{tabular}{|c|c|c|}
\hline & $\begin{array}{ll}\text { Mandiri Finance } \\
\text { Pengurus berkomitmen } \\
\text { memajukan koperasi dan } \\
\text { anggota }\end{array}$ & 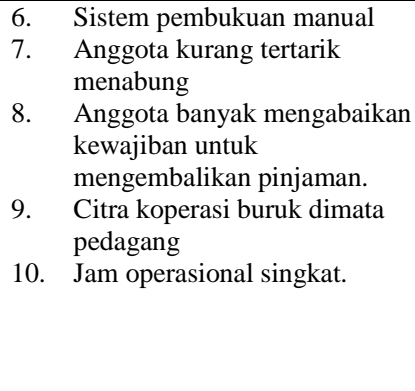 \\
\hline Faktor Eksternal & & \\
\hline $\begin{aligned} & \text { Peluang } \\
& \text { 1. } \text { Koperasi melakukan } \\
& \text { kegiatan produksi bermitra } \\
& \text { dengan perusahaan konveksi } \\
& \text { memproduksi pakaian anak } \\
& \text { 2. } \text { Menarik anggota baru } \\
& \text { karena jumlah pedagang } \\
& \text { 3. } \text { yang banyak } \\
& \text { Bekerjasama dengan pihak } \\
& \text { UPTD Pemda Depok yang } \\
& \text { bertanggungjawab } \\
& \text { mengelola pasar } \\
& \text { 4. } \text { Wacana bantuan dana dari } \\
& \text { Kementrian Koperasi } \\
&\end{aligned}$ & $\begin{array}{cl}\text { Strategi SO } \\
\text { 1. } & \text { Meningkatkan kualitas SDM } \\
\text { 2. } & \text { Perlusan usaha tidak saja } \\
& \text { berupa simpan pinjam } \\
\text { 3. } & \text { Meningkatkan komitmen } \\
& \text { pengurus } \\
\text { 4. } & \text { Memperkuat pangsa pasar }\end{array}$ & $\begin{array}{ll}\text { Strategi WO } \\
\text { 1. } & \text { Menambah modal baru } \\
\text { 2. } & \text { Memperketat syarat pinjaman } \\
\text { 3. } & \text { Meningkatkan komitmen } \\
& \text { anggota } \\
\text { 4. } & \text { Meningkatkan promosi } \\
\text { 5. } & \text { Meningkatkan kualtitas } \\
& \text { pelayanan }\end{array}$ \\
\hline $\begin{array}{cl}\text { Ancaman } \\
\text { 1. } & \begin{array}{l}\text { Adanya pasar kaget yang } \\
\text { berunculan di akhir pekan }\end{array} \\
2 . & \begin{array}{l}\text { Munculnya supermarket } \\
\text { besar yang mengalihkan }\end{array} \\
\text { minat konsumen berbelanja } \\
\text { 3. } & \begin{array}{l}\text { Fasilitas pasar yang tidak } \\
\text { memadai }\end{array} \\
\text { 4. } & \begin{array}{l}\text { Banyaknya kios yang sepi } \\
\text { penjual dan pembeli } \\
\text { terutama di lantai atas } \\
\text { tempat koperasi berada }\end{array} \\
\end{array}$ & $\begin{array}{cl}\text { Strategi ST } \\
\text { 1. Membangun fasilitas yang } \\
\text { memadai } \\
\text { 2. Meningkatkan kepercayaan } \\
\text { anggota dan calon anggota } \\
\text { 3. } \\
\text { Menetapkan strategi pemasaran }\end{array}$ & 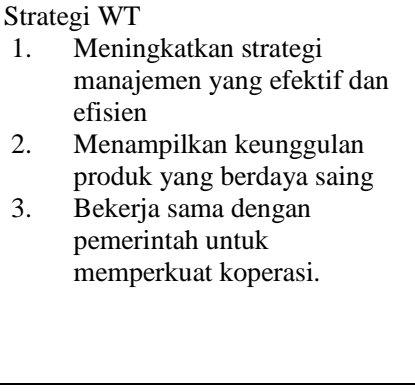 \\
\hline
\end{tabular}

Berdasarkan Tabel 4 di atas diperoleh kolom-kolom strategi-strategi yang diperoleh dari analisa data-data faktor internal dan eksternal KPPD. Terdapat 4 jenis strategi yang dihasilkan yaitu strategi SO, strategi WO, strategi ST dan strategi WT.

\section{Pembahasan}

Menurut (Rangkuti F. , 2010) matriks IE didasarkan pada dua dimensi kunci dengan keterangan bahwa skor total bobot EF berada pada sumbu Y sedangkan skor bobot total IF berada pada sumbu X. Matriks IE secara garis besar dbagi menjadi 3 bagian, yaitu:

1. Ketentuan untuk divisi-divisi yang masuk dalam sel 1, 2, dan 4 digambarkan sebagai tumbuh dan membangun (growth and build). Maka strateginya adalah strategi intensif (penetrasi pasar, pengembangan pasar dan pengembangan produk) atau strategi integratif (integrasi ke belakang, ke depan dan horizontal) 
2. Ketentuan untuk divisi-divisi yang masuk pada sel 3, 5 dan 7 dapat ditangani dengan baik melalui strategi menjaga dan mempertahankan (bold and maintenance). Maka strategi yang dipilih adalah penetrasi pasar dan pengembangan produk.

3. Ketentuan untuk divisi-divisi yang masuk pada sel 6, 8 dan 9 adalah panen atau divestasi.

Berdasarkan skor faktor internal (2.025) dan eksternal $(2,95)$ maka dapat disimpulkan bahwa Koperasi Produksi Pedagang Kota Depok (KPPD) berada pada irisan sel 5 dengan interval skor 2,00-3,00 atau rata-rata sedang yang bermakna growth konsentrasi integrasi horizontal. Dengan demikian strategi manajemen KPPD adalah menjalankn growth konsentrasi melalui integrasi horizontal, yaitu fokus pada peningkatan pertumbuhan asset dan profit koperasi dengan cara mengembangkan produk baru, meningkatkan kualitas produk dan jasa atau meningkatkan akses pasar lebih luas.

Perincian dari strategi growth konsentrasi integrasi horizontal dijabarkan berdasarkan hasil matriks SWOT pada Tabel 4 diatas. Dengan demikianstrategi manajemen KPPD dalam meningkatkan kinerja dan pelayanan untuk anggota adalah sebagai berikut:

\section{Strategi SO:}

1. Meningkatkan kualitas SDM. Saat ini pengurus aktif yang selalu berada di tempat hanya 2 orang ditambah 1 orang sekretaris yang merangkap sebagai petugas yang menarik cicilan pinjaman setiap harinya. Oleh sebab itu diperlukan penambahan personel sehingga tidak lagi terjadi perangkapan tugas. Peningkatan kualitas pula dapat dilakukan dengan aktif menghadiri pelatihan yang diadakan oleh Dewan Koperasi Indonesia (DEKOPINDA)

2. Perlusan usaha tidak saja berupa simpan pinjam. Saat ini produk yang ditawarkan Koperasi Produksi Pedagang Kota Depok adalah simpan pinjam. Sedangkan pada awal berdirinya koperasi ini mempunyai kegiatan simpan pinjam dan produksi

3. Meningkatkan komitmen pengurus

4. Peningkatan komitmen pengurus dengan bekerja sesuai dengan AD ART yang telah ditetapkan setiap RAT

5. Menambah pasar baru. Koperasi sebaiknya melakukan kegiatan penambahan pasar baru seperti membuka cabang di daerah lain yang lokasinya strategis

\section{Strategi ST:}

1. Membangun fasilitas yang memadai seperti fasilitas kerja yang dilengkapi internet, pengadaan ATK yang lengkap sehingga anggota dapat lebih sering berinteraksi

2. Meningkatkan kepercayaan anggota dan calon anggota dengan cara secara berkala rajin mengundang anggota dalam RAT dan menarik calon anggota dengan cara jemput bola 
3. Menetapkan strategi pemasaran berupa peningkatan kesejahteraan pengurus yang dapat dilakukan dengan cara pemberian insentif, fasilitas asuransi jaminan kerja.

\section{Strategi WO:}

1. Menambah modal baru dengan cara meningkatkan kegiatan promosi sehingga nasabah akan bertambah.

2. Memperketat syarat pinjaman dengan cara memberlakukan masa jatuh tempo dan penetapan sanksi berupa denda bagi anggota yang terlambat membayar.

3. Meningkatkan komitmen anggota berupa mempertegas aturan simpan pinjam dengan memberikan syarat tertentu. Ini ditempuh agar tidak semua anggota dapat terlalu leluasa meminjam

4. Meningkatkan promosi yang dapat menarik anggota dan calon anggota berupa melakukan promosi melalui media cetak ataupun melalui media sosial.

5. Meningkatkan kualtitas pelayanan kepada anggota

\section{Strategi WT:}

1. Meningkatkan strategi manajemen yang efektif dan efisien agar dapat mengurangi ancaman dan meminimalisasi kelemahan yang dimiliki koperasi.

2. Menampilkan keunggulan produk yang berdaya saing. Cara ini dapat berupa memodifikasi produk yang ditawarkan. Langkah ini diambil untuk menghilangkan citra buruk yang selama ini masih melekat pada pedagang pasar terhadap koperasi.

3. Bekerja sama dengan pemerintah untuk memperkuat koperasi. Pemerintah perlu menata dan memperkuat peran koperasi di pasar untuk meningkatkan perekonomian para pedagang pasar. Selama ini, banyak koperasi di pasar tradisional yang mati suri. Selain itu koperasi dimanfaatkan segelintir orang untuk mencari keuntungan dari para pedagang. Koperasi pedagang pasar dapat memainkan peran penting. Koperasi ini dapat berfungsi membuka simpanan dan memberi pinjaman kepada para pedagang. Koperasi ini juga bisa berperan sebagai penyalur bahan pokok dan pinjaman lunak dari pemerintah (keuanganLSM, 2015)

\section{SIMPULAN}

Strategi manajemen KPPD dalam meningkatkan kinerja dan pelayanan untuk anggota dapat ditempuh dengan cara melakukan strategi growth konsentrasi integrasi horizontal dimana koperasi harus fokus pada usaha meningkatkan asset dan profit, mengembangkanproduk barudan saluran pemasaran baru secara kontinu dan meningkatkan kualitas barang dan jasa yang ditawarkan

Penjabaran strategi secara spesifik yang dapat dilakukan oleh Koperasi Produksi Pedagang Kota Depok adalah Strategi SO dengan cara meningkatkan kualitas SDM, Perlusan usaha tidak saja berupa simpan pinjam, meningkatkan komitmen pengurus, Memperkuat pangsa pasar. Strategi ST dengan cara 
membangun fasilitas yang memadai, meningkatkan kepercayaan anggota dan calon anggota, menetapkan strategi pemasaran. Strategi WO dengan cara menambah modal baru, memperketat syarat pinjaman, meningkatkan komitmen anggota, meningkatkan promosi, meningkatkan kualitas pelayanan, Strategi WT dengan cara meningkatkan strategi manajemen yang efektif dan efisien, menampilkan keunggulan produk yang berdaya saing, bekerja sama dengan pemerintah untuk memperkuat koperasi.

\section{DAFTAR PUSTAKA}

Arikunto, S. (2006). Metode Penelitian Kualitatif. Jakarta: Bumi Aksara.

Daryanto, \& Setiabudi, I. (2014). Konsumen dan Pelayanan. Yogyakarta: Gava Media.

Hanny, Kurniawati, K., Waruwu, B. S., \& Pribadi, R. (2017). Analisis Reidentifikasi Empat Masalah Utama Koperasi di Kabupaten Subang sebagai Dasar Penyusunan Strategi. Jurnal Akuntansi, 9(No.1), 54-73.

keuanganLSM. (2015, Oktober 14). KeuanganLSM. Dipetik Juli 1, 2019, dari keuanganlsm.com: http://keuanganlsm.com/peran-koperasi-pedagangpasar-perlu-diperkuat/

Mawikere, L. (2014). Analisis Pengakuan Pendapatan dan Beban pada Koperasi Listrik PT PLN (Persero) Wilayah Suluttenggo Menurut PSAK No.27. Jurnal LPPM bidang EkoSosBudKum, 1(No.2), 41-55.

Moeheriono. (2012). Pengukuran Kinerja Berbasis Kompetensi. Jakarta: Raja Grafindo Perkasa.

Nassaji, H. (2015). Qualitative and Descriptive Research : Data Type versus Data Analysis. Language Teaching Research Volume 19, 129-132.

Pardede, M. (2011). Manajemen Strategik dan Kebijakan Perusahaan Pedoman Utama Pembuatan Rencana Strategik (Restra) atau Rencana Pembangunan Jangka Menengah (RPJM). Jakarta: Mitra Wacana Media.

Pearce II, J. A., \& Robinson, Jr, R. B. (2008). Manajemen Strategis: Formulasi, Implementasi dan Pengendalian. Jakarta: Salemba Empat.

Rangkuti, F. (2006). Analisis SWOT: Teknik Membedah Kasus Bisnis. Jakarta: PT Gramedia Pustaka Utama.

Rangkuti, F. (2010). Strategic Management : Manajemen Strategis Konsep. Jakarta: PT. Gramedia Pustaka Utama.

Sari, G. N. (2016). Analisis SWOT Strategi Pemasaran pada Koperasi Indonesia Berjamaah. Jakarta: UIN Syarif Hidayatullah.

Setyawan, R. (2015). Penerapan Analisis SWOT sebagai Landasan Merumuskan Strategi Pemasaran Usaha Jasa Sewa Mobil AMAN-AMIN Transport Tours and Travel Ambarketawang Sleman Yogyakarta. Yogyakarta: Lumbung Pustaka UNY. 
Sindonews, T. (2018, Agustus 21). ekbis.sindonews.com. Dipetik Juni 28, 2019, dari sindonews.com: http://ekbis.sindonews.com/read/1331996/12-tahunlpdb-kumkm-menyalurkan-dana-bergulir-rp85-triliun-15348711

Sudarsono, \& Edilius. (2005). Koperasi dalam Teori dan Praktek. Jakarta: Rineka Cipta.

Sugiyono. (2007). Metode Penelitian Kuantitatif, Kualitatif dan R\&D. Bandung: Alfabeta.

Suhartono, I. (2011). Strategi Pengembangan Koperasi Berorientasi Bisnis. Jurnal Among Makarti, 4(No.7), 33-47.

Sukandarmidi. (2012). Metodologi Penelitian: Pentunjuk Praktis untuk Peneliti Pemula. Yogyakarta: Gadjah Mada University Press. 